\title{
Board behavior's impact on entrepreneurial orientation in public enterprises
}

\author{
Timo Tremml ${ }^{1}$ [ - Sabine Löbbe ${ }^{2} \cdot$ Andreas Kuckertz $^{1}$ (i)
}

Accepted: 23 June 2021 / Published online: 7 July 2021

(c) The Author(s) 2021

\begin{abstract}
Public enterprises find themselves in increasingly competitive markets, a situation that makes having an entrepreneurial orientation (EO) an urgent need, given that EO is an indispensable driver of performance. Research describes politicians delaying the strategic change of public enterprises when serving as board members, but empirical evidence of the impact of board behavior on EO in public enterprises is lacking. We draw on stakeholder-agency theory (SAT) and resource dependence theory (RDT) and use structural equation modeling (SEM) to investigate survey data collected from 110 German energy suppliers that are majority government owned. Results indicate that board strategy control and board networking do not seem to predict EO on first sight. Closer analysis reveals a board networking-EO relationship depending on ownership structure. Remarkably, we find that it is not the usually suspected local municipal owner who hinders EO in our sample organizations but minority shareholders engaging in board networking activities. The results shed light on the intersection of governance and entrepreneurship with special reference to the fine-grained conceptualization of RDT.
\end{abstract}

Keywords Entrepreneurship · Public enterprise · Entrepreneurial orientation · Board · Governance

\section{Introduction}

Public enterprises commit to guarantee and improve public value while facing a permanent struggle with other enterprises in liberalized and increasingly competitive markets (Mühlemeier, 2019). Such an environment makes an entrepreneurial

Andreas Kuckertz

andreas.kuckertz@uni-hohenheim.de

1 Entrepreneurship Research Group, University of Hohenheim, Wollgrasweg 49, 70599 Stuttgart, Germany

2 Reutlingen Energy Center for Distributed Energy Systems and Energy Efficiency, Reutlingen University, Alteburgstraße 150, 72762 Reutlingen, Germany 
orientation (EO) an urgent need, as it enables competitive advantages and promotes the success and performance of organizations, regardless of whether they are publicly or privately owned (Caruana et al., 2002; Meynhardt \& Diefenbach, 2012; Rauch et al., 2009). Nevertheless, recent work shows EO among public organizations to be less prevalent than that among their private counterparts (Hinz \& Ingerfurth, 2013), corroborating that barriers to entrepreneurial activities in the public sector remain unclear (Cinar et al., 2019). One "particular object of interest" deals with the behavior of the board of directors (BoD) (Hinna et al., 2010, p. 133). The sparse existing research focuses exclusively on private-sector board behavior and indicates a positive effect on EO (e.g., Deman et al., 2018). Research in the public sector indicates a negative effect when the governmental owner closely controls its enterprise (e.g., Lioukas et al., 1993; Smith, 2012). Such findings are strengthened by accounts describing politicians as largely delaying the strategic change of public enterprises when serving as board members (Calabrò et al., 2013; Padilla-Angulo, 2020) or-in simple terms - as the "essence of the problem" (Sørensen, 2007, p. 1046). Despite the societal and democratic relevance of the BoD in public enterprises (Cahan et al., 2005) and board behavior potentially revealing differences in the public and private sectors being looked for (Hinna et al., 2010; Liddle \& McElwee, 2019), empirical evidence is surprisingly lacking. Therefore, the purpose of the article is to answer the research question: To what extent does board behavior predict public enterprises' EO?

We draw our predictions from stakeholder-agency theory (SAT) and resource dependence theory (RDT) when examining a primary dataset of 110 German public enterprises and contribute to the literature in three main ways. First, besides outstanding exceptions (e.g., Meynhardt \& Diefenbach, 2012), public-sector studies on EO remain surprisingly scarce. We shed light on unknown predictors of entrepreneurial undertakings in public enterprises (Cinar et al., 2019). Importantly, instead of relying on the commonly used but implausible input-output model (Dalton et al., 1998), which refers to observable characteristics such as board size and its direct effect on firm performance (Finkelstein \& Mooney, 2003; Gabrielsson, 2007), we base our assumptions on the mediating role of board behavior and EO (Coombes et al., 2011). Second, although research on the relationship between the BoD and EO has recently attracted attention in private-sector research (e.g., Deman et al., 2018), this article illuminates the little-understood topic of board behavior and its influence on EO in public enterprises. By doing so, the study reveals a missing link between board strategy control and EO, thus addressing the widespread prejudice that a BoD dominated by politicians will have negative effects for the organization in question (e.g., Calabrò et al., 2013; Padilla-Angulo, 2020; Sidki \& Boll, 2019; Sørensen, 2007). Third, despite the relevance of RDT in the public sector (Pfeffer \& Salancik, 1978; Roberts \& King, 1991), we support the idea for a fine-grained conceptualization (Casciaro \& Piskorski, 2005). Challenging common ideas of favorable ownership stakes by private-sector-dominated (i.e., mixed) enterprises and interorganizational networks (Inoue et al., 2013; Kolloch \& Reck, 2017; Monteduro, 2014) and underscored with the potential positive effects of board interlocks on performance (Drees \& Heugens, 2013; Pfeffer \& Salancik, 1978), we reveal the board networking-EO relationship changes from positive to negative when such 
enterprises hold minority shares of the public enterprise. In doing so, we extend foundational research (e.g., Kaczmarek et al., 2014; Zona et al., 2018) that relies on input-output modeling.

\section{Theoretical framework and hypotheses development}

\subsection{The role of entrepreneurial orientation in public enterprises}

While the academic discussion about public enterprises has undergone a recent revival, research on the phenomenon remains scarce (Bernier \& Reeves, 2018). Public enterprises have financial motives, among others (e.g., a social responsibility to sustain and improve public value), and compete with enterprises in liberalized markets. We build our reasoning by relying on the ideas of corporatization (Calabrò et al., 2013) and define public enterprises as those more than $50 \%$ owned by government but that are a separate legal entity. Therefore, we challenge the outdated view of the public sector being an entity (Liddle \& McElwee, 2019) and follow endeavors to clearly define the sample's boundaries (Miller, 2011) by accounting for different ownership structures. A typical example of minority shareholders with increasing importance are hub firms, ${ }^{1}$ as they are able to exert a far-reaching power on their network enterprises (Baudry \& Chassagnon, 2012; Kolloch \& Reck, 2017), implicating important effects on the governance system, as the different owners cannot be seen as an entity with common interests (Calabrò et al., 2013).

Public enterprises' focal situation, with an increasingly hostile environment due to liberalized markets and competitive rivals (Mühlemeier, 2019), requires the enhancement of an organization's EO (Covin \& Slevin, 1989). EO is a firm-level strategic posture with an essential growth orientation (Covin \& Slevin, 1989; Dess \& Lumpkin, 2005). It describes how innovatively and proactively an enterprise operates with respect to business-related risk propensity (Covin \& Slevin, 1989; Miller, 1983). Innovativeness encapsulates the pursuit of and ability to produce innovations, resulting, for example, in product introductions as an act of new entry (Covin $\&$ Miller, 2014). This includes not only the number of new lines of products and services but also potentially radical and disruptive changes of products and service lines (Covin \& Slevin, 1989). Proactiveness is about anticipating and shaping future needs, as well as being ahead of competitors in terms of introducing novel products instead of simply imitating the actions of competitors (Covin \& Slevin, 1989; Lumpkin \& Dess, 2001). Accordingly, active new entry is an essential part of behaving proactively and seizing opportunities (Lumpkin \& Dess, 2001). Risk-taking is about undertaking bold actions with a chance of very high returns instead of taking cautious incremental steps toward achieving a firm's objectives (Covin \& Slevin,

\footnotetext{
1 Lacking a clear definition of networks (Provan et al., 2007), we define hub firms as enterprises that set up an interorganizational network and find themselves in the middle of it (Jarillo, 1988; Kolloch \& Reck, 2017). They hold minority shares in members of their network, engage in knowledge exchange, and also lead/coordinate their network (Dhanaraj \& Parkhe, 2006; Kolloch \& Reck, 2017).
} 
1989). By seizing potential opportunities, firms accept the risk of failure in terms of potentially costly wrong decisions (Covin \& Slevin, 1989).

Scholars recently started to interpret EO as a form of corporate entrepreneurship (CE), as a high incidence of entrepreneurial events indicates a firm having a strong EO (Covin \& Wales, 2019). While both concepts are closely related, EO as an organizational attribute is a behavioral construct, while CE can be defined as an activity within the organization (Covin \& Wales, 2019). Overall, EO mediates the relationship between the organization's environment and its performance (Rosenbusch et al., 2013) by promoting ambidextrous innovations (Kollmann \& Stöckmann, 2014).

When examining the field of entrepreneurship research, it becomes obvious that it is biased toward the private sector (Smith, 2012). This results in public-sector research still dealing with fundamental questions of EO's relevance and applicability (e.g., Liddle \& McElwee, 2019; Morris \& Jones, 1999; Sadler, 2000). These questions include whether EO leads to higher performance in the public sector, even though performance indicators in the public sphere are determined by multiple, potentially contrary objectives such as public value and profitability (Bernier, 2014; Liddle \& McElwee, 2019; Moore, 1995). On first sight, a simple transfer of the concept of entrepreneurship into the public sector seems inappropriate, with research arguing that it might conflict with democratic values (Bellone \& Goerl, 1992), and empirical measuring of public entrepreneurship could differ from classic CE (Mack et al., 2008).

Importantly, research commonly describes the public sector as a monopolistic entity with a focus on academic institutions and monopolistic governmental organizations (Bernier, 2014; Papenfuß \& Keppeler, 2020), even though significant differences between public organizations exist (e.g., Morris \& Jones, 1999; Smith, 2012). In this vein-and potentially in contrast to other public entities and board expectations-entrepreneurship in public enterprises fundamentally resembles entrepreneurship in traditional corporations, as they are far more profit-oriented than in the past (Bernier, 2014; Morris \& Jones, 1999) and also aspire to growth-oriented activities (Kearney et al., 2008, 2010). Besides this differentiation in the public sphere, it remains that public-sector organizations strive for innovations (Mack et al., 2008), and studies on different forms of EO in different public sector contexts show a positive impact on a variety of performance indicators, such as the explorative innovation activities of German public-sector employees (Kraus et al., 2019) or (cost) effectiveness, resource efficiency, and overall performance among Australian publicsector entities (Caruana et al., 2002).

Consequently, EO is a valuable concept for public organizations (Liddle \& McElwee, 2019), supporting the meta-analysis of Rauch et al. (2009) that suggests organizations with a strong EO benefit not only from improving financial but also nonfinancial outcomes. However, EO remains at a lower level in public enterprises than in their private and non-profit counterparts (Hinz \& Ingerfurth, 2013). This calls for a comparison of the predictors of EO in the public sector and private sector. Similarities in both sectors can be drawn, such as insufficient human resources (Kellermanns \& Eddleston, 2006; Weber et al., 2014), missing (financial) incentives (Bysted \& Jespersen, 2014; Perry et al., 2010), and conflicts among co-workers arising from 
the innovative behavior of individual employees (Shih \& Susanto, 2011; Tremml, 2020) that can hamper entrepreneurial activities. Differences between both sectors can be recognized in the external environment, as public enterprises are subject to specific external regulations (Bernier, 2014; Smith, 2014). Furthermore, intraorganizational differences exist, as public organizations have to deal with greater goal ambiguity (Meynhardt \& Diefenbach, 2012), and public-sector employees might ignore current market needs more regularly, as they are not used to working in competitive environments (Mühlemeier, 2019).

With respect to the governing body, comparison is difficult, as the relationship between politics and public enterprises' EO remains particularly unclear (Cinar et al., 2019). Previous literature in this area has predominantly used the implausible input-output model (Dalton et al., 1998), which refers to observable characteristics such as board size and its direct effect on firm performance (Finkelstein \& Mooney, 2003; Gabrielsson, 2007). This model leads to different results than would an examination of actual board behavior and its impact on EO (Gabrielsson, 2007). Public-sector research still relies on the questionable input-output modeling (e.g., Bozec \& Dia, 2007; Garrone et al., 2013), whereas private-sector research has sporadically overcome this shortcoming, indicating a positive effect of board behavior on EO and innovations (e.g., Deman et al., 2018; Gabrielsson, 2007). Importantly, public-sector research indicates a negative effect, as politicians on the board are described as potential barriers to entrepreneurial activities and their outcomes (e.g., Calabrò et al., 2013; Lioukas et al., 1993; Padilla-Angulo, 2020; Smith, 2012), and stakeholder-oriented board theory predicts board behavior hampering growthoriented concepts like EO (Hill \& Jones, 1992). Consequently, public-governancerelated determinants merit more investigation by opening the "black box of board of directors" in public enterprises (Calabrò et al., 2013, p. 858) in order to explain why the EO of public enterprises remains at a lower level than that of their private counterparts (Hinz \& Ingerfurth, 2013).

\subsection{The role of corporate governance in the public sector}

Corporate governance "refers to the rules and procedures by which corporations are directed and controlled" (Grossi \& Reichard, 2008, p. 608). Compared to the "classic" version of corporate governance in the private sector, public-sector concepts are extended by democratic legitimation and public service obligations (Klausen \& Winsvold, 2021). We refer to public corporate governance (PCG), which includes public enterprises in liberalized markets, as they perform services via separate companies that are more independent from the state than classic government agencies (Mühlemeier, 2019). To ensure democratic control and to legitimize the enterprise democratically (Klausen \& Winsvold, 2021), the public shareholders nominate board members who represent politics and public administration to the board, according to the shares in the enterprise and shareholder agreement (Calabrò et al., 2013). Accordingly, the board in our sample is likely to be mainly composed of local politicians and also to act as an intermediary between the citizens [as the ultimate (majority) owner of the enterprise (Blankart, 
1983)] and the enterprise itself, represented by its management (Hinna et al., 2010). Therefore, the public sector deals with multiple principal-agent relationships (Cuervo \& Villalonga, 2000) that require closer analysis, which is often done through the theoretical lens of agency theory (Hinna et al., 2010).

With regard to public enterprises' corporatization process, the general requirement of corporate governance is a result of the separation of ownership and control (Jensen \& Meckling, 1976). According to agency theory, the board is in a strong position to limit managerial actions on a strategic level that might be detrimental to shareholders' expectations, resulting in enhanced firm performance (Fama \& Jensen, 1983; Westphal, 1999). This can be achieved by monitoring the actions of the management (Hillman \& Dalziel, 2003), which reduces the costs of potentially self-interested actions by the management (Fama \& Jensen, 1983).

While most of the work on corporate governance relies on this narrow agency perspective (Boivie et al., 2016; de Villiers \& Dimes, 2021; Huse et al., 2011), recent research discusses the modification of traditional agency theory, such as by suggesting the BoD's (political) self-interests as a potential barrier to organizational change (e.g., Hoppmann et al., 2019; Smith, 2014). Interweaving an agency and stakeholder perspective leads to the political role of a BoD being to determine the goals and policies of the public enterprise (Hinna \& Scarozza, 2015), underlining their potential impact on the strategy of the focal enterprise. The SAT focusses on the relationship between the stakeholders and the enterprise rather than merely on the (narrow) relationship between the shareholders and the firm in traditional agency theory (Hill \& Jones, 1992). This distinction is crucial, as the identification of all relevant stakeholders (including the citizens) and their interests is indispensable for designing corporate governance in the public sphere, with its multiple principal-agent relationships (Calabrò et al., 2013; Cuervo \& Villalonga, 2000; Grossi \& Reichard, 2008; Hinna \& Scarozza, 2015). Another modification considers the short-run disequilibrium through market adjustment processes characterized by friction that enable the inclusion of theories of power like RDT (Hill \& Jones, 1992), which is especially relevant in the public sector (Lioukas et al., 1993; Roberts \& King, 1991). The concept of RDT deals with an organization's interaction with its environment to reduce external dependencies through networking and legitimization activities (Pfeffer \& Salancik, 1978), and the theory has attracted substantial approbation for its predictions in the field of organizational research (Drees \& Heugens, 2013). RDT highlights the ability of the board to provide resources from the external environment to the focal enterprise, resulting in enhanced firm performance (Hillman \& Dalziel, 2003), as increases in EO require a significant amount of resources (Covin \& Slevin, 1989).

We therefore address two perspectives on the board and their impact on EO as a firm-level strategic posture: RDT is concentrated on the board as a provider of resources, while SAT is concerned with control activities on a strategic level (Hill \& Jones, 1992; Pfeffer \& Salancik, 1978). In this vein, combining SAT and RDT was recently suggested as offering a "powerful conceptual [foundation] that can be used to address issues of board governance in entrepreneurship research" (Gabrielsson \& Huse, 2017, p. 53). 


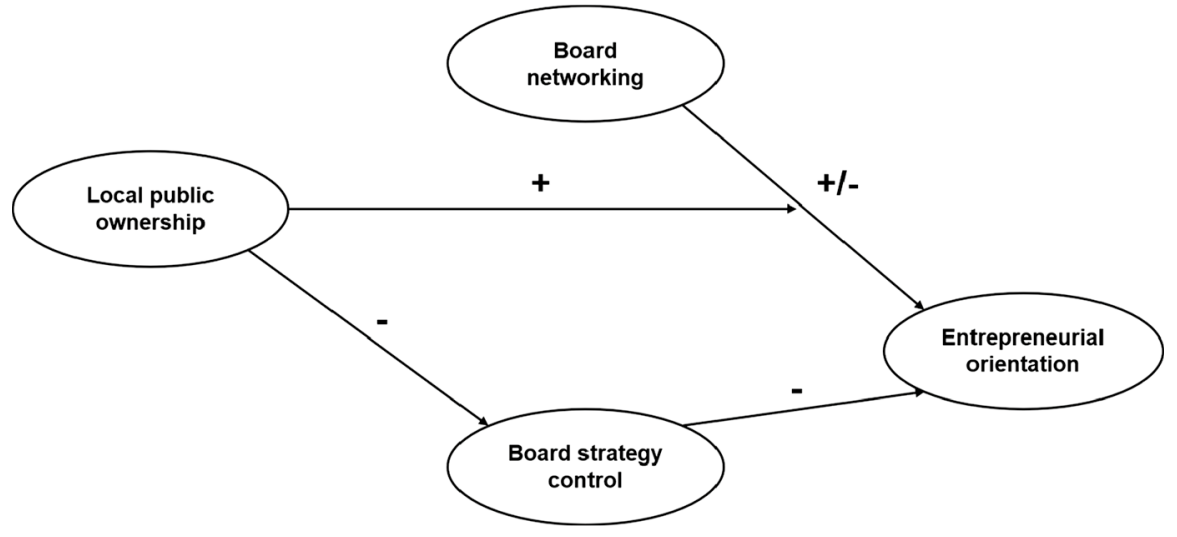

Fig. 1 Theoretical model

These two perspectives can be reflected in public enterprises' focal situation. Public enterprises are in a striking dilemma in which they are expected both to act entrepreneurially and to innovate, while at the same time are potentially hindered by close monitoring with political/social objectives (Greer et al., 2003). In this vein, the board might support entrepreneurial activities by the provision of resources according to RDT, while at the same time hamper such activities by blocking the diversification of public enterprises by stressing their control activity according to SAT. To investigate the unclear relationship between entrepreneurship and local politics, we examine the promising but little-understood topic of board behavior relating to networking and strategy control as predictors of public enterprises' EO. We embed our model in the context of the study of corporatization that enables minority shareholdings by other enterprises. Therefore, ownership structure serves as an indicator of board capital/composition (Li, 1994; Mizruchi, 1996) while also directly predicting board behavior (Desender et al., 2013; Hideto Dato et al., 2020).

The corresponding theoretical model is shown in Fig. 1, which we discuss in detail directly below.

\subsection{Board behavior predicting entrepreneurial orientation in the context of corporatization}

\subsubsection{The role of local public ownership in board strategy control}

In general, the local governmental owner has an increasing interest in and duty to pursue responsible business development and to encourage entrepreneurial thinking in its enterprise (Meynhardt \& Diefenbach, 2012). In line with this development, the relevance of BoDs' behavior as a key factor in the boards' performance is no longer only recognized in the private sector but also in the public sphere (Cahan et al., 2005). Both aspects indicate that differences in ownership might be irrelevant to board behavior. This means that a modern $\mathrm{BoD}$ of a public enterprise in a liberalized market is likely to be largely aligned with classical models of corporate 
governance (Chambers \& Cornforth, 2010), which implies that the board acts in the best interest of the enterprise.

However, SAT suggests that the multiple principal-agent relationships with numerous stakeholders found in the public sector (Cuervo \& Villalonga, 2000) might increase coordination problems and the inertia of collective action (Hill \& Jones, 1992). This issue can afflict BoDs with a high proportion of serving politicians at the same time: They might simply aim to be representative of the local voters' perspectives and seek primarily to maintain the status quo, which would undermine their discharging their role to the best of their ability (Coombes et al., 2011). Furthermore, and quite commonly in the public sector, weaker controls might be explained by a lack of incentives and by capacity problems (Boivie et al., 2016; Cahan et al., 2005; Hillman \& Dalziel, 2003). Referring to a lack of incentives, politicians might have little incentive to monitor the activities of the organization because they will face little scrutiny from local citizens. Citizens' monitoring activities are inefficient because they have weak property rights and high transaction costs (Blankart, 1983; Davies, 1971). The issue of monitoring is a concern because citizens are reliant on the monitoring activity of the board owing to dispersed ownership, as the citizens are the ultimate owners of the public enterprise (Blankart, 1983; Desender et al., 2013). Referring to capacity problems, local governmental owners might assign more ambiguous and potentially conflicting objectives than shareholders like hub firms (Shleifer \& Vishny, 1997). This ambiguity might reduce potential monitoring capacity among the politicians on the board representing local government (Boivie et al., 2016). Thus, we hypothesize:

$H_{1}$ : Local public ownership negatively affects board strategy control.

\subsubsection{Board strategy control and entrepreneurial orientation}

$\mathrm{Be}$ it in the private or the public sector, $\mathrm{BoD}$ involvement in the monitoring and ratification of an enterprise's activities may affect a firm's entrepreneurial posture (Gabrielsson, 2007). Studies on the relationship have focused exclusively on the private sector, revealing that a BoD's control task is a potential positive influence on a firm's entrepreneurial attributes (Deman et al., 2018; Gabrielsson, 2007; Gabrielsson \& Politis, 2009; Schepers et al., 2013), for example, as the board challenges the top management to support innovation and increase the long-term valuation of the firm (Fama \& Jensen, 1983).

With regard to the public sector, however, board members who are local politicians have strong obligations to external stakeholders (Olsen et al., 2017), which might also negatively influence their behavior when they sit on private boards and attempt to perform a "watchdog role" (Huse \& Rindova, 2001, p. 173). In that scenario, local politicians might not act in the best interests of the firm. Even though all stakeholders are assumed to have a general interest in the continuing existence of the firm, SAT also states that a BoD might have little incentive to support entrepreneurial activities that could adversely affect the quality of life of stakeholder groups (Hill \& Jones, 1992). Attempts by management to increase their power over different stakeholders through extending the firm's customer base via a diversification of products and/or markets might encounter resistance by the BoD, as the investment 
demanded by diversification can be viewed as an inefficient use of resources (Hill \& Jones, 1992). Such diversification is encouraged by the inherent growth orientation of EO (Dess \& Lumpkin, 2005), for example, via the introduction of new products as an act of new entry (Covin \& Miller, 2014). Therefore, a BoD that blocks managerial initiatives through heavy involvement in ratifying and monitoring an enterprise's strategy might contribute to organizational inertia and lower performance (Hill \& Jones, 1992; Hoppmann et al., 2019; Shleifer \& Vishny, 1994). Prior public-sector literature indicates that state involvement is negatively associated with innovativeness and performance (e.g., Bradshaw et al., 1992; Lioukas et al., 1993; Ramamurti, 1986; Smith, 2012), and board members who were not primarily appointed because of their political competence were shown to positively influence the EO of public enterprises (Smith, 2012). Accordingly, we hypothesize:

$\mathrm{H}_{2}$ : Board strategy control negatively affects public enterprises' EO.

\subsubsection{The role of local public ownership in BoDs' networking-EO relationships}

In addition to its strategy control role, the BoD is well positioned to establish important links to (external) resources and stakeholders that potentially stimulate EO (Huse, 2005b; Miller, 2011). These links may enable the board to provide unique resource bundles that create a competitive advantage for the enterprise (Coombes et al., 2011; Huse \& Rindova, 2001). An EO encompasses actions like new product introductions (Covin \& Miller, 2014; Covin \& Slevin, 1989) and early responses to potential opportunities (Lumpkin \& Dess, 2001). Such activities often require a significant volume of resources and might involve a considerable risk of failure (Rosenbusch et al., 2013). Public enterprises therefore require legitimization for venturing, especially if the new activity is highly innovative and different in relation to previous products and services (Covin \& Slevin, 1989; Pfeffer \& Salancik, 1978). Prior private-sector research already indicates a slightly positive correlation of $\mathrm{BoD}$ service provision (incorporating networking) and EO (Bauweraerts \& Colot, 2017; Deman et al., 2018). For public enterprises, there might be social ties between the local politicians on the board and the management that improve resource delivery and the organization's EO (Dicko et al., 2020; Meynhardt \& Diefenbach, 2012; Westphal, 1999). As the local BoD is encouraged to legitimate public enterprises' entrepreneurial activities to its local stakeholders (Pfeffer \& Salancik, 1978), these social ties on the local level might be especially helpful to those translating the resources directed to EO. This leads to the first part of our next hypothesis:

$H_{3 a}$ : Local public ownership positively moderates the relationship between the BoD's networking task and a public enterprise's EO.

To be more specific, interorganizational relationships such as equity holdings are expected to lead to relational advantages and positive outcomes such as interorganizational learning and stable resource provision (Drees \& Heugens, 2013; Kolloch \& Reck, 2017; Pfeffer \& Salancik, 1978). As ownership structures directly influence board composition (Li, 1994; Mizruchi, 1996), there might be board members appointed by minority shareholders such as hub firms. Board composition is suggested to be highly relevant to board interlocks, which occur when "a person affiliated with one organization sits on the board of directors of another organization" 
(Mizruchi, 1996, p. 271). These interlocks might support interfirm network ties that potentially help enterprises to reduce external resource dependency and consequently improve innovativeness and firm performance (Helmers et al., 2017; Pfeffer \& Salancik, 1978). However, we argue that this does not hold true for enterprises like hub firms when serving as minority shareholders on the board of the focal public enterprise. Zona et al. (2018) found that interlocking directorates may have positive or negative effects on firm performance, depending on resource availability and ownership structure. In this vein, Kaczmarek et al. (2014) also found a negative relationship between interlocking and firm performance in financial and utility companies. These opposing effects on firm performance indicate that in addition to positive effects flowing from reduced resource dependency, for example via interfirm network ties, there might also be negative effects on firm performance. Those negative effects might stem from board interlocks as an instrument of corporate control (Casciaro \& Piskorski, 2005; Mizruchi, 1996) or limiting enterprises' ability to act autonomously by restricting a pluralist set of resource providers (Baudry \& Chassagnon, 2012; Drees \& Heugens, 2013). Both might be achieved by enabling interlocking BoDs to exert power and control over the focal firm (Casciaro \& Piskorski, 2005; Pfeffer \& Salancik, 1978). Powerful minority shareholders might encourage high levels of board networking activity to increase the resource dependence of the focal firm (Casciaro \& Piskorski, 2005). As resource dependency might repress EO (Rosenbusch et al., 2013), we state in the second part of our hypothesis:

$H_{3 b}$ : The direction of the relationship between the BoD's networking task and a public enterprise's EO changes from positive to negative when other enterprises hold minority shares in the focal firm.

\section{Methods}

\subsection{Research design and sample}

Our study focuses on energy suppliers in Germany that are majority-owned by the government. Many of these enterprises are former monopolists but today operate in a liberalized energy market experiencing environmental uncertainties in terms of competitiveness and business transformation (Mühlemeier, 2019), for example, as a result of the German energy system transformation (Energiewende) that includes aspects like the switch from fossil fuels to renewable energy sources and digitalization (Mazzucato, 2018). Additionally, Germany has a high level of urban selfgovernance and places considerable importance on the concept of public services; one example is the running of public buses, which are often provided by locally owned utilities (Mühlemeier, 2019). Consequently, the environment of these enterprises is increasingly hostile and therefore requires the enhancement of an organization's EO (Covin \& Slevin, 1989), with the BoD charged with delivering the expectations of the municipality and its citizens (Pfeffer \& Salancik, 1978). We limit our scope because research in a specific context and on a particular organization type may limit generalization but increase the validity of the research findings (Lomberg et al., 2017; Miller, 2011). Furthermore, we question the common perspective of the 
public sector being an entity (Liddle \& McElwee, 2019) despite the variety among public-sector organizations regarding the drivers and outcomes of entrepreneurship (Bysted \& Hansen, 2015; Smith, 2012). Therefore, we focus on the competitive business segments in the energy sector.

Primary data on public enterprises with a focus on governance and EO remains scarce (Daiser et al., 2017; Meynhardt \& Diefenbach, 2012). In line with prior studies, we decided to use a single respondent study because the top management is the key informant on board behavior and EO, especially when boards meet relatively rarely, as in the present context (Bauweraerts \& Colot, 2017; Rauch et al., 2009; Zattoni et al., 2015). When determining the population, we ensured that the enterprises in question had a $\mathrm{BoD}$ and followed prior EO studies requiring a minimum of 10 employees (Arzubiaga et al., 2018; Kollmann \& Stöckmann, 2014). We crosschecked multiple databases, leading to the identification of a total of 620 enterprises.

As data collection via a single-respondent approach and in a single timeframe might lead to common method bias (CMB), we followed the guidelines of Podsakoff et al. (2003) and Podsakoff et al. (2012) as well as prior studies in this sensitive field (Minichilli et al., 2009; Zattoni et al., 2015). We aimed to reduce CMB at the survey design stage by (1) guaranteeing the respondents anonymity and confidentiality, (2) placing independent and dependent variables far away from each other within the survey, and (3) stating clearly that there were no correct or incorrect answers and (4) that different opinions about the issues addressed in the questionnaire were possible. Additionally, we conducted 20 pretests with people from the energy sector (with characteristics as close as possible to the key informant), the public administration, and academic experts in order to fine-tune the questionnaire, for example regarding a consistent understanding of terms and reducing item ambiguity (Podsakoff et al., 2012).

Data collection took place from March until May 2019. We contacted each potential respondent or their assistant personally via phone to qualify the firm and invite the key informant to participate. That personal invitation secured permission to distribute 274 questionnaires, resulting in 116 responses. After excluding questionnaires with inappropriate respondents and/or missing data, our final dataset consists of 110 responses (108 CEOs, two general managers), representing a very satisfying final response rate of $40.1 \%$.

After data collection, we checked for CMB using Harman's single-factor test (Podsakoff et al., 2003). The largest of the identified factors accounts for only $17.2 \%$ of the variance, while the remaining eight account for $42.3 \%$ (Podsakoff \& Organ, 1986). As this test provides only a first indication, we conducted a full collinearity test and found no bias, as all factor-level variance inflation factors are smaller than 3.3 (Kock, 2015; Kock \& Lynn, 2012). Both tests indicate that CMB should not be a problem in our study.

To check for non-respondent bias, we collected objective data via the previously used Bisnode database (Kollmann \& Stöckmann, 2014). When Bisnode did not provide information, annual corporate reports were examined. Following prior studies in the field (e.g., Carpenter \& Westphal, 2001; Deman et al., 2018), we relied on the Kolmogorov-Smirnov test (Siegel \& Castellan, 1988) to check for significant differences regarding firm size and CEO age between respondents and non-respondents. 
Table 1 Sample description

\begin{tabular}{|c|c|c|c|c|}
\hline Sample characteristics & $\mathrm{N}=110$ & $\%$ & Mean & $\begin{array}{l}\text { Standard } \\
\text { deviation } \\
\text { (SD) }\end{array}$ \\
\hline \multicolumn{5}{|l|}{ Firm size (employees) } \\
\hline Between 10 and 50 employees & 40 & 36.4 & 155.79 & 235.51 \\
\hline Between 51 and 100 employees & 26 & 23.6 & & \\
\hline Between 101 and 150 employees & 17 & 15.5 & & \\
\hline More than 150 employees & 27 & 24.5 & & \\
\hline \multicolumn{5}{|l|}{ Local public ownership } \\
\hline $50 \%$ or less & 0 & 0 & 3.17 & 0.92 \\
\hline Between $>50 \%$ and $<75 \%$ & 38 & 34.5 & & \\
\hline Between $\geq 75 \%$ and $<100 \%$ & 15 & 13.6 & & \\
\hline $100 \%$ & 57 & 51.8 & & \\
\hline \multicolumn{5}{|l|}{ Respondent age } \\
\hline $30-39$ & 7 & 6.4 & 52.84 & 7.11 \\
\hline $40-49$ & 22 & 20.0 & & \\
\hline $50-59$ & 58 & 52.7 & & \\
\hline $60-69$ & 23 & 20.9 & & \\
\hline \multicolumn{5}{|l|}{ Respondent tenure } \\
\hline Less than 5 years & 32 & 29.1 & 9.82 & 7.47 \\
\hline Between 5 and 10 years & 38 & 34.5 & & \\
\hline Between 11 and 15 years & 15 & 13.6 & & \\
\hline More than 15 years & 25 & 22.7 & & \\
\hline
\end{tabular}

We also checked for differences in terms of enterprises' headquarters/location (at the level of federal state) and form of legal entity using chi-square tests (Bauweraerts \& Colot, 2017). Overall, we did not find significant differences between the two groups.

An overall description of the sample is shown in Table 1.

To check for validity, the self-reported measures reported in Table 1 were correlated with secondary data whenever possible, showing significant correlations for firm size $(r=0.993, p<0.01, n=54)$, local public ownership $(\rho=0.929$, $\mathrm{p}<0.01, \mathrm{n}=54)$, respondent age $(\mathrm{r}=0.998, \mathrm{p}<0.01, \mathrm{n}=52)$, and respondent tenure $(r=0.983, p<0.01, n=53)$. The results indicate the validity of the self-reported measures (Kollmann \& Stöckmann, 2014).

\subsection{Variables and measures}

All measurement scales were borrowed from previous studies. Importantly, the study measured the respondents' perceptions. To ensure a correct translation from English to German, two experienced researchers followed the forward-backward translation technique advocated by Brislin (1970). Most items were measured on 
Likert-type scales. Here we used 5-point scales, as the original 7-point scales could easily be rescaled without affecting the mean, skewness, or kurtosis (Dawes, 2008). Combined with endpoint labeling, this is the best choice when researchers want to relate variables and estimate linear relations using structural equation modeling (SEM) (Weijters et al., 2010), for example because of higher criterion validity.

\subsubsection{Independent variables}

3.2.1.1 Local public ownership Prior studies were criticized for measuring public or private ownership structures dichotomously (Bruton et al., 2015) and for ignoring potential differences between giant state-owned enterprises and public enterprises on a more local level (Florio, 2013). Therefore, we distinguished between a simple majority stake ( $>50 \%$ to $<75 \%$ ), a qualified majority stake $(75 \%$ to $<100 \%)$, and full ownership (100\%) by local municipalities and/or districts. As stated in Sect. 2, we additionally took the peculiarities of our sample and the findings of comparable research into account (Kolloch \& Reck, 2017) and defined minority shareholdings from other enterprises (such as other energy suppliers) as non-public-albeit they are potentially majority-owned by government. This action ensured the research had clear boundaries, as we relied on a specific organization type (Lomberg et al., 2017; Miller, 2011) and overcame the traditional and inappropriate view of the public sector representing an entity (Bysted \& Hansen, 2015; Liddle \& McElwee, 2019).

3.2.1.2 Board networking To measure a BoD's ability to provide legitimacy and to establish important links to external resources and stakeholders for the public enterprise, we relied on the multi-item Likert scale anchored with fully disagree (1) and fully agree (5) provided by Minichilli et al. (2009), which is essentially based on the suggestion of Huse (2005a).

\subsubsection{Dependent variables}

3.2.2.1 Board strategy control To measure a BoD's ability to perform its strategy control task, we measured the involvement in the ratification stage and the follow-up monitoring stage with a construct based on the board involvement in decision control scale provided by Gabrielsson and Winlund (2000) and validated by Gabrielsson (2007). We took the findings of Gabrielsson and Politis (2009) into account and focused on the strategy control perspective of the board. All six items were measured on a Likert scale anchored with fully disagree (1) and fully agree (5).

3.2.2.2 Entrepreneurial orientation To understand "what EO looks like" (Covin \& Wales, 2012, p. 681), we relied on the predominantly used second-order reflectivereflective Miller/Covin and Slevin construct (Covin \& Slevin, 1989). We included the findings of Lumpkin and Dess (2001) and replaced one item on proactiveness (Typically adopts a very competitive "undo-the-competitors" posture) with the item A strong tendency to be ahead of other competitors in introducing novel ideas or products, as the latter was a better fit with the dimension in question (Brändle et al., 
2019; Kollmann \& Stöckmann, 2014). In general, a higher overall score indicates higher EO, while lower scores indicate a more conservative orientation (Covin \& Slevin, 1989; Green et al., 2008). Following prior research (Kollmann \& Stöckmann, 2014), all nine items were measured using a 5-point semantic differential-type scale.

\subsubsection{Control variables}

Following previous studies in the realms of board and EO research, we controlled for variables regularly showing explanatory power for the endogenous variables. On the environmental level, we controlled for social orientation, as public enterprises often have to provide potentially unprofitable services of general interest [i.e., services that are crucial for life, such as public transport, in an affordable manner to all citizens (Mühlemeier, 2019)] while satisfying profit expectations in competitive markets (Mühlemeier, 2019; Olsen et al., 2017). Prior work suggests an impact on board behavior, for example, due to "political visibility" (Lioukas et al., 1993, p. 647). This visibility may increase citizens' monitoring activity of politicians taking a seat on the supervisory board (Lioukas et al., 1993; Mizrahi \& Minchuk, 2019; Niskanen, 1971; Salancik, 1979). Simultaneously, such social-oriented activities may reduce corporate (market) performance (Cuervo \& Villalonga, 2000; Shleifer \& Vishny, 1994), as it consumes a significant volume of resources necessary to increase a firm's EO (Covin \& Slevin, 1989; Hill \& Jones, 1992). We based our 5-point semantic differential scale on that of Lioukas et al. (1993). We addressed concerns reported in the literature over impaired reliability by providing a contextspecific and unambiguous example within the construct (Lee \& Duffy, 2019; Sackett \& Larson, 1990). A higher overall score indicates greater non-commercial obligations by addressing demands regardless of the costs incurred, and is therefore more likely to be associated with (social) public service objectives. A lower overall score indicates a stronger commercial orientation and fewer restrictions flowing from the enterprise being allowed to exclude unprofitable customers from accessing its offerings (Lioukas et al., 1993). Furthermore, we controlled for hostility, as prior studies showed environmental discontinuities to have an impact on board behavior and EO (Green et al., 2008; Lioukas et al., 1993; Smith, 2012). Hostility was measured with the multi-item Likert scale provided by Green et al. (2008). On the board level, we controlled for board activity and board knowledge. Board activity was measured by asking how long an ordinary board meeting usually lasts (in hours) (Arzubiaga et al., 2018). Board knowledge was measured with the multi-item Likert scale provided by Machold et al. (2011), previously validated by Minichilli and Hansen (2007). On the firm level, we controlled for past performance, as crisis contexts in terms of bad performance affect board behavior and entrepreneurial undertakings (Eddleston et al., 2012; Gabrielsson, 2007; Minichilli \& Hansen, 2007). As focusing exclusively on financial outcomes would be inappropriate (Bruton et al., 2015), past performance was measured with a statement based on Caruana et al. (2002) which accounts for the overall performance of the enterprise for the last three years compared to other energy suppliers, therefore indicating the firm's goals, objectives, and aspiration levels (Kirchhoff, 1977; Lumpkin \& Dess, 1996). 


\subsubsection{Measurement model assessment}

In order to evaluate our measurement model, we first tested the reliability of the reflective constructs by examining $\rho_{\mathrm{A}}$, composite reliability (CR), and Cronbach's alpha (CA) (Hair et al., 2019). We deleted item numbers 1 and 4 of hostility to retain $\rho_{\mathrm{A}}, \mathrm{CR}$, and CA values close to or higher than 0.7 for all constructs, which indicates construct reliability (Hair et al., 2019). Second, the average variance extracted shows scores higher than 0.5, indicating convergent validity (Hair et al., 2019). Third, discriminant validity is tested via the Fornell-Larcker criterion (Fornell \& Larcker, 1981), cross-loadings, and the heterotrait-monotrait ratio of correlations (Henseler et al., 2015). All three tests display values fitting their suggested thresholds, indicating discriminant validity (Hair et al., 2019).

\subsection{Analytical approach}

The analytical approach used is SEM, which is appropriate when examining multiple cause-effect relations with latent constructs (Hair et al., 2011). Although this method features heavily in (private-sector) management-related research (Hair et al., 2019), it is little used in PCG research (Daiser et al., 2017). We used partial least squares (PLS), as we rely on a prediction perspective of the model with early-stage theory development (Hair et al., 2019; Moreno \& Casillas, 2008). The PLS analysis is also particularly suitable for testing interaction effects (Mitchell et al., 2008; Sirén et al., 2012). Like prior comparable studies in the field (e.g., Arzubiaga et al., 2018), we used SmartPLS 3 (Ringle et al., 2015), the most widely applied PLS-SEM software (Hair et al., 2018). We used a path-weighting scheme, as our model includes a second-order reflective construct (Sarstedt et al., 2019). To test the significance of the paths, we conducted the complete and bias-corrected bootstrap procedure with 5,000 subsamples (Hair et al., 2018). The moderator analysis was performed via a two-stage approach, as suggested by Becker et al. (2018). Overall, our proposed model can be reasonably run with 90 cases (Chin, 1998). The available sample size of 110 cases is consequently more than sufficient for our analysis (Hair et al., 2018).

\section{Results}

Before presenting the results of the proposed hypotheses, we offer Table 2 to display the correlation matrix, mean values, and standard deviations of the variables.

The data reveal significant correlations between board characteristics and board behavior, replicating the findings of previous private-sector studies (e.g., Gabrielsson \& Winlund, 2000; Minichilli et al., 2009). Despite suggestions in the literature, we do not find a significant relationship between social orientation and board behavior (e.g., Lioukas et al., 1993; Mizrahi \& Minchuk, 2019), board networking and hostility (Huse, 2007), or ownership structure and EO (Hinz \& Ingerfurth, 2013). In line with prior suggestions in the literature, we find a significant negative correlation 


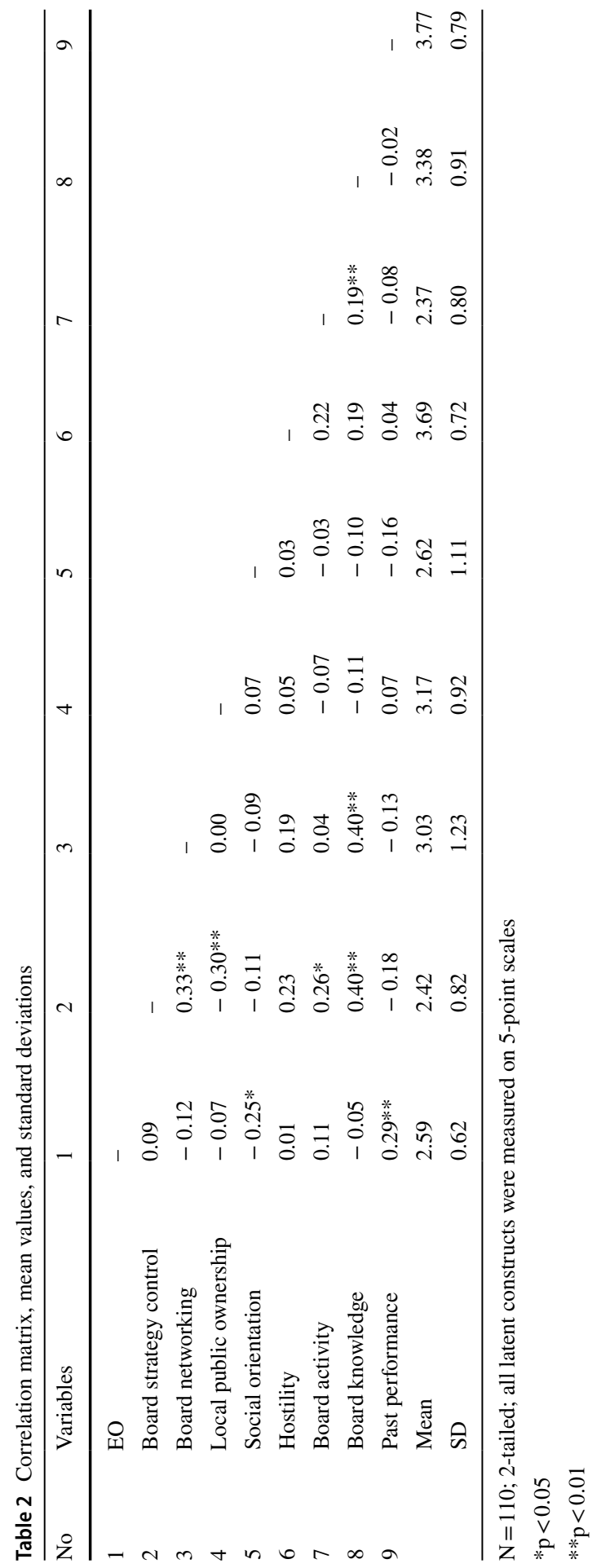




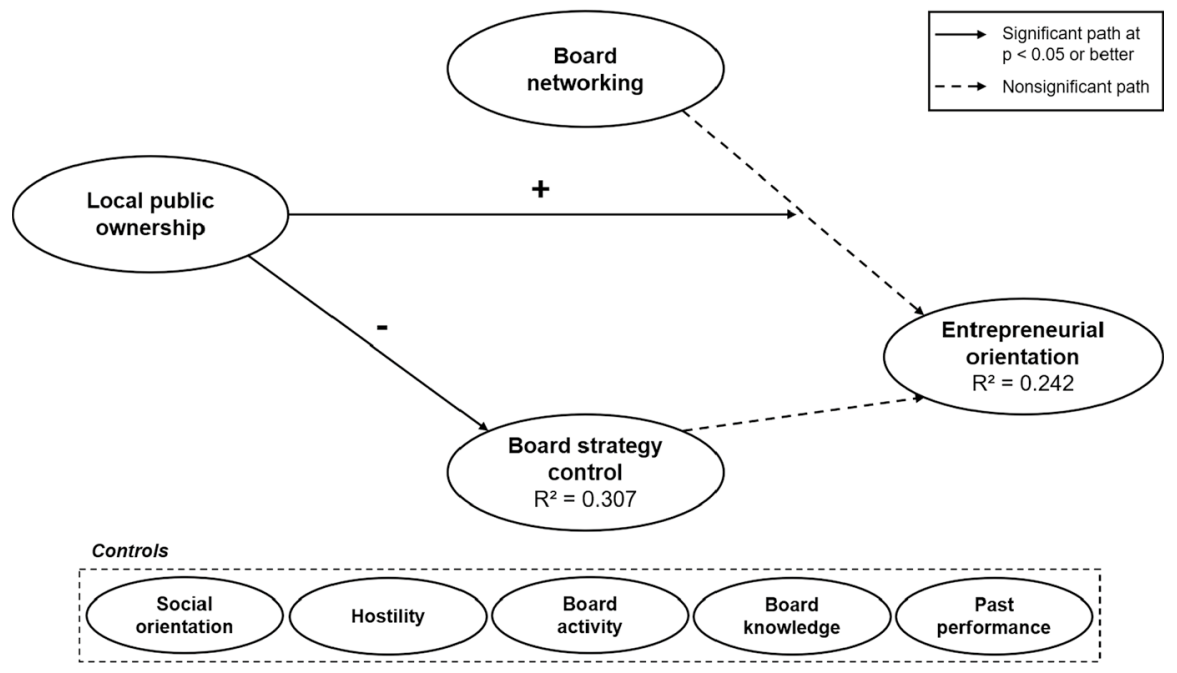

Fig. 2 Hypotheses results (one-tailed)

between social orientation and EO (Cuervo \& Villalonga, 2000; Shleifer \& Vishny, 1994). Importantly, we find a significant positive correlation between past performance and EO, a situation that research has been more skeptical about in the public sphere (Liddle \& McElwee, 2019) than in the private sector (Rauch et al., 2009).

We show the results of our tested hypotheses in Fig. 2, which illustrates that that the model is significant with relatively high in-sample explanatory power $\left(R^{2}=0.307\right.$ for board strategy control; $\mathrm{R}^{2}=0.242$ for EO) (Hair et al., 2019). The Stone-Geisser criterion $\left(\mathrm{Q}^{2}\right)$ was calculated via a blindfolding procedure with an omission distance of 7.0 (Tenenhaus et al., 2005). $\mathrm{Q}^{2}$ is clearly greater than zero for both endogenous variables, supporting the interpretation of the model's predictive accuracy for these constructs (Hair et al., 2019).

The control variable social orientation has no significant effect on board strategy control (path $=-0.092, \mathrm{p}=0.12, \mathrm{f}^{2}=0.012$ ), but a small negative effect on EO (path $=-0.226, \mathrm{p}<0.01, \mathrm{f}^{2}=0.063$ ). Hostility and board activity do not show a significant effect on board strategy control (hostility: path $=0.162, p=0.11$, $\mathrm{f}^{2}=0.035$; board activity: path $=0.126, \mathrm{p}=0.09, \mathrm{f}^{2}=0.021$ ) or on EO (hostility: path $=-0.014, \mathrm{p}=0.45, \mathrm{f}^{2}=0.000$; board activity: path $=0.141, \mathrm{p}=0.08$, $\left.\mathrm{f}^{2}=0.023\right)$. Board knowledge has a small positive effect on board strategy control (path $=0.310, \mathrm{p}<0.01, \mathrm{f}^{2}=0.127$ ), but no significant effects on EO (path $=-0.151$, $\left.\mathrm{p}=0.09, \mathrm{f}^{2}=0.022\right)$. Past performance has a small negative effect on board strategy control ( path $=-0.165, \mathrm{p}<0.05, \mathrm{f}^{2}=0.038$ ) and a small positive effect on $\mathrm{EO}$ (path $\left.=0.248, \mathrm{p}<0.01, \mathrm{f}^{2}=0.073\right)$.

Turning to the proposed hypotheses, our results show that local public ownership has a small negative effect on board strategy control (path $=-0.247, \mathrm{p}<0.01$, $\left.\mathrm{f}^{2}=0.085\right)$, supporting Hypothesis 1 . With regard to the relationship of board strategy control and EO, we do not find a significant effect on $\mathrm{EO}$ (path $=0.167, \mathrm{p}=0.07$, $\left.\mathrm{f}^{2}=0.025\right)$; therefore, there is no support for Hypothesis 2, with an opposite but 


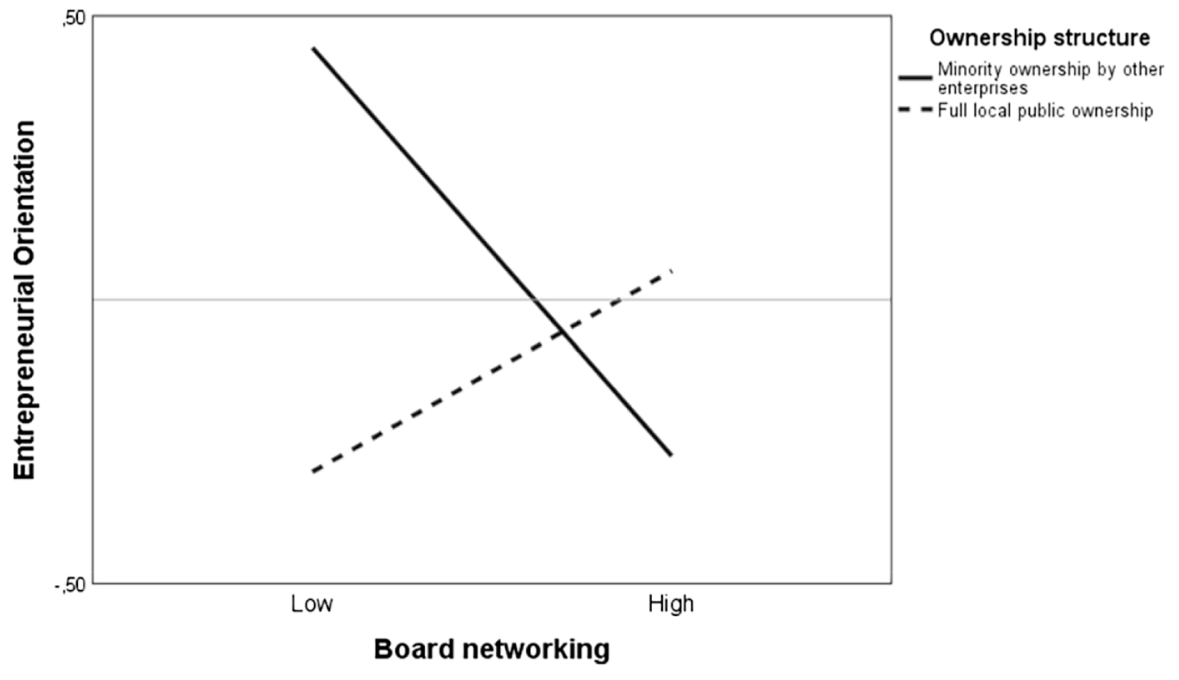

Fig. 3 The moderating effect of local public ownership on the board networking-EO relationship

nonsignificant direction of the hypothesized effect. The model shows a small positive moderation effect of local public ownership on the relationship between board networking and EO (path $=0.247, \mathrm{p}<0.05, \mathrm{f}^{2}=0.077$ ), which supports Hypothesis 3a. Furthermore, the direction of the relationship seems to depend on the ownership structure (Fig. 3).

On average, that is, without the interaction term, board networking has no significant effect on EO (path $=-0.122, \mathrm{p}=0.16, \mathrm{f}^{2}=0.014$ ). For enterprises wholly owned by their local municipalities and/or districts, the direction of the path of board networking and EO is positive, whereas for public enterprises with minority shareholders in the sample, the direction changes to negative. Therefore, we also find support for Hypothesis $3 b$.

In order to account for the multiple perspectives involved in the study's underlying relationship between the $\mathrm{BoD}$ and top management, the findings were discussed in a workshop in October 2019 with board members from potential minority shareholders, CEOs of the enterprises in question, and consultants regularly attending board meetings in this particular context. The aim was to ensure the face validity of the findings from a practical perspective.

\section{Discussion}

Public enterprises are in a striking dilemma in which they are expected to act entrepreneurially and innovate, while at the same time working under the potential constraints imposed by the close monitoring and political/social objectives of local government (Greer et al., 2003). Shedding light on this dilemma, the current article addressed the overall research question: To what extent does board behavior predict public enterprises' EO? 
We reveal ownership structure to be an important concept predicting board strategy control and the board networking-EO relationship. This is a finding that has considerable implications for theory and practice.

\subsection{Implications for theory}

Our study contributes novel theoretical insights at the intersection of governance and entrepreneurship. With reference to the two behavioral dimensions (strategy control and networking), we rely on the conceptual foundation of SAT and RDT that might be capable theories "to address issues of board governance in entrepreneurship research" (Gabrielsson \& Huse, 2017, p. 53), as their use makes it possible to consider board behavior inside and outside the boardroom.

First, although organizational research has found substantial support for RDT, following Pfeffer and Salancik (1978), that indicates a positive effect on performance (Drees \& Heugens, 2013), the detailed findings presented here reveal that board networking activity affects EO differently depending on ownership structure. This means that interorganizational arrangements like interfirm network ties and equity holdings that potentially reduce external resource dependency and consequently improve firm performance-as originally intended by RDT (Pfeffer \& Salancik, 1978) - might not have that power in the context studied here. We therefore advance the idea of a fine-grained theory of RDT (Casciaro \& Piskorski, 2005) by opening resource delivery for potential diametral effects in order to provide a deeper understanding of interorganizational action. To date, comparable research has relied on input-output modeling (e.g., Drees \& Heugens, 2013; Kaczmarek et al., 2014; Zona et al., 2018). We advance theory by closely examining the relationship between board behavior and EO as relevant mediators.

Second, our study also presents a new perspective on board strategy control and its missing link with EO in the public sector. While private-sector studies already indicate the BoD control task has a positive effect on entrepreneurial posture and innovativeness (Deman et al., 2018; Gabrielsson, 2007; Gabrielsson \& Politis, 2009), the public-sector research indicates a negative effect of a BoD composed predominantly of politicians (e.g., Calabrò et al., 2013; Padilla-Angulo, 2020; Sidki \& Boll, 2019; Sørensen, 2007) and refers to a narrow state-control perspective (e.g., Lioukas et al., 1993; Smith, 2012). Although board members nominated by the local public owners seeming to be less involved in ratifying and monitoring the strategy of the enterprise is a concern-on the grounds that public-sector reforms seek to create a modern public-sector BoD largely aligned with classical models of corporate governance (Chambers \& Cornforth, 2010) despite weak property rights and high transaction costs of local citizens - the missing link between strategy control and EO might be intentional. The board of a public enterprise is installed to ensure its democratic legitimization. Consequently, board members from local politics might have different governance logics than minority shareholders (Olsen et al., 2017): Should the politicians on the board of public enterprises push those enterprises toward a more entrepreneurial posture through the exercise of control mechanisms, as suggested in previous private-sector studies? Prior research has already discussed 
potential conflicts between democratic values (such as social orientation) and entrepreneurship (Bellone \& Goerl, 1992), and the topic continues to stimulate academic discussion (Liddle \& McElwee, 2019). Interestingly, this is also accounted for in SAT, as it incorporates the stakeholders' general interest in the continuing existence of the enterprise (Hill \& Jones, 1992). Therefore, a BoD might balance conservative and entrepreneurial orientations and counteract entrepreneurial intentions only up to the point where the continuing existence of the enterprise is not in doubt.

\subsection{Implications for practice}

With reference to a management perspective, entering into resource dependencies via minority shareholders like hub firms might represent an entrepreneurial decision of the public enterprise. Activities like the outsourcing of risky undertakings without clear and certain outcomes might be part of public enterprises' strategy to increase long-term value and ensure adequate profits (OECD, 2015), given that excessive risk-taking without stressing the other EO dimensions of innovativeness and/or proactiveness at the same time might be detrimental to performance (Kollmann \& Stöckmann, 2014; Lomberg et al., 2017).

With reference to a policy perspective, recent board codes and guidelines (e.g., for municipally owned enterprises in Germany (Association of German Cities, 2009) and global guidelines for state-owned enterprises (OECD, 2015)), primarily adopt a monitoring perspective while stressing the importance of the qualification requirements for a $\mathrm{BoD}$, focusing on board composition and size, and restating the idea of minimizing political interference. Importantly, and mirroring some identified gaps in the academic literature (Boivie et al., 2016), the above guides pay little attention to multidimensional board behavior beyond common board practices and legal duties (such as networking activity), even though this multidimensional perspective might help to achieve the BoD's goal of acting in the best interest of their public enterprise. Furthermore, local municipal BoDs still seem to be less involved in strategy control than enterprises holding minority shares, despite the former's board activity having great societal and democratic relevance and citizens relying on the monitoring activity of the board because of those citizens' dispersed ownership (Desender et al., 2013). In order to increase citizens' involvement and incentives to monitor politicians on the board, the implementation of innovative, digitalized ways of information and participation might be fruitful (Calabrò et al., 2013).

\subsection{Limitations and future research}

Three limitations of our study illuminate promising avenues for further research that will help to extend our knowledge about entrepreneurship and board practices in public enterprises.

First, even though we avoid the limitations of input-output models that can undermine the behavioral approach (Dalton et al., 1998; Gabrielsson, 2007), we are aware that the study measures single respondents' perceptions of BoD behavior and EO. However, the consideration of multiple respondents might result in even more 
bias (Bauweraerts \& Colot, 2017; Minichilli et al., 2009). We recognize that BoDs meet relatively rarely, and that could limit their ability to develop informed perceptions of the constructs in question (Podsakoff et al., 2012; Zattoni et al., 2015). Further research might address this limitation by relying on ethnographic techniques, which would make it possible to investigate live activities and behavior inside and outside the boardroom on a longitudinal basis and from an individual-level perspective (Höglund et al., 2018; Hoppmann et al., 2019; Sievinen et al., 2020). Importantly, such techniques might be especially fruitful regarding the ownership-related differences in board behavior and their impact on EO. The study's results call for an investigation of the governance logics of local public owners and minority shareholders, as "municipal corporate boards have become meeting-places for different institutional logics" (Olsen et al., 2017, p. 393), and such logics are not directly measurable through questionnaires, as in the present study (Thornton \& Ocasio, 1999). Accordingly, and with special reference to the revealed interaction effect, it would be valuable to also consider potential effects on minority shareholders to address the fact that the current research limited its investigation to one side of the relationship (Zona et al., 2018).

Second, while this study's approach takes top management's perception of board behavior into account, we are aware that some of the measurement scales are relatively untried (Boivie et al., 2016; Huse et al., 2011). However, we rely on previously used constructs in our study and take more recent findings into account (e.g., Gabrielsson \& Politis, 2009). Furthermore, we addressed concerns over the reliability of the social orientation scale by providing a context-specific and unambiguous example within the construct (Lee \& Duffy, 2019; Sackett \& Larson, 1990). Nevertheless, future research might support establishing valid measurement scales by following the specific steps of a scale development process (Clark \& Watson, 1995).

Third, we admit that a single-industry study limits the generalizability of the findings. However, we follow the recent call of Miller (2011) and the EO-related findings of Lomberg et al. (2017) that research in a specific context and on a particular organization type may increase the validity of the research findings, because, for example, using samples that are too heterogenous might create a risk of promoting a weak understanding of the sample's boundaries (Miller, 2011), even though those boundaries are especially important in governance and entrepreneurship research (Boivie et al., 2016; Lomberg et al., 2017). Following this line of argumentation, we address the outdated view of the public sector being a homogenous monolith (Liddle \& McElwee, 2019), as recent research reveals remarkable differences between public-sector organizations regarding entrepreneurial behavior (Bysted \& Hansen, 2015; Smith, 2012, 2014). However, comparative studies between public and private enterprises working in the same market environment might also be promising, as recent research calls for a broadening of the concepts of CE and EO (e.g., Covin \& Wales, 2019; Liddle \& McElwee, 2019). Overall, future research in different contexts could help to provide further insights, especially regarding RDT, in that examining the relationship between board networking and EO as moderators could provide deeper insights into a hypothesized mechanism (Baron \& Kenny, 1986).

Table 3 summarizes the findings of the study in conjunction with their implications for research and practice and promising avenues for future research. 


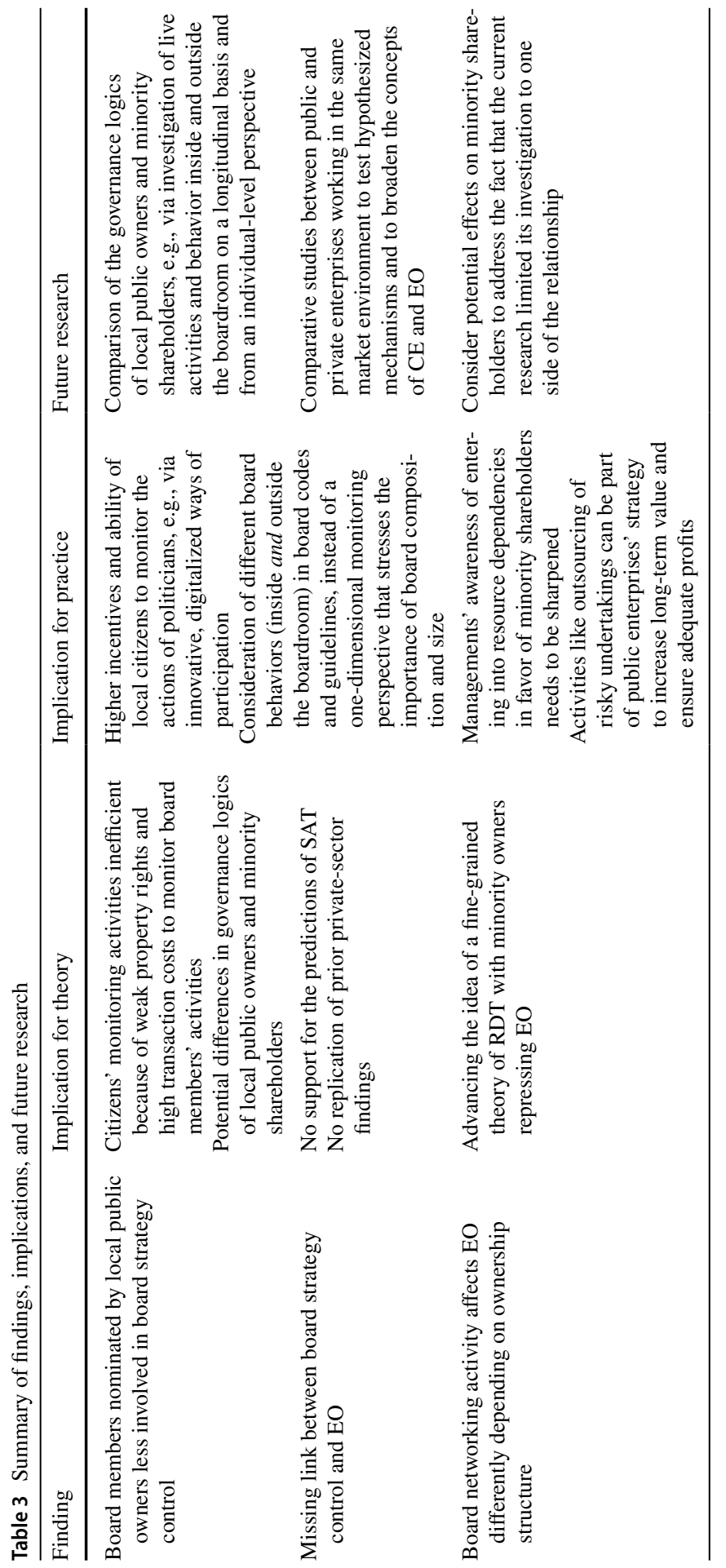




\section{Conclusion}

This study challenges prior literature that suggests the municipal owner of a public enterprise is the source of the inertia hindering entrepreneurial activities. We reveal minority shareholders exerting a negative effect on public enterprises' EO when engaging in networking activities. Consequently, this study advances research at the intersection of entrepreneurship and governance and clearly helps in understanding the effects of board behavior on EO in public enterprises.

Acknowledgements The authors are grateful for the valuable comments provided by the participants of the $23^{\text {rd }}$ G-Forum in Vienna, Austria.

Author contributions TT: Conceptualization, Formal Analysis, Investigation, Data Curation, Writing - Original Draft, Project Administration. SL, AK: Conceptualization, Validation, Resources, Writing Review and Editing, Supervision.

Funding Open Access funding enabled and organized by Projekt DEAL. This work was supported by the Ministry for Science, Research and Art of Baden-Wuerttemberg, Germany.

\section{Declarations}

Conflict of interest The authors declare that they have no conflict of interest.

Open Access This article is licensed under a Creative Commons Attribution 4.0 International License, which permits use, sharing, adaptation, distribution and reproduction in any medium or format, as long as you give appropriate credit to the original author(s) and the source, provide a link to the Creative Commons licence, and indicate if changes were made. The images or other third party material in this article are included in the article's Creative Commons licence, unless indicated otherwise in a credit line to the material. If material is not included in the article's Creative Commons licence and your intended use is not permitted by statutory regulation or exceeds the permitted use, you will need to obtain permission directly from the copyright holder. To view a copy of this licence, visit http://creativecommons.org/licen ses/by/4.0/.

\section{References}

Arzubiaga, U., Kotlar, J., De Massis, A., Maseda, A., \& Iturralde, T. (2018). Entrepreneurial orientation and innovation in family SMEs: Unveiling the (actual) impact of the board of directors. Journal of Business Venturing, 33(4), 455-469.

Association of German Cities. (2009). Eckpunkte für einen Public Corporate Governance Kodex (PCGK) für kommunale Unternehmen [Key Points for a Public Corporate Governance Code (PCGK) for Municipal Enterprises]. Retrieved June 22, 2020, from http://www.staedtetag.de/imperia/md/conte nt/dst/eckpunkte_pcgk_kommunale_unternehmen.pdf.

Baron, R. M., \& Kenny, D. A. (1986). The moderator-mediator variable distinction in social psychological research: Conceptual, strategic, and statistical considerations. Journal of Personality and Social Psychology, 51(6), 1173-1182.

Baudry, B., \& Chassagnon, V. (2012). The vertical network organization as a specific governance structure: What are the challenges for incomplete contracts theories and what are the theoretical implications for the boundaries of the (hub-) firm? Journal of Management and Governance, 16(2), 285-303.

Bauweraerts, J., \& Colot, O. (2017). Exploring nonlinear effects of family involvement in the board on entrepreneurial orientation. Journal of Business Research, 70, 185-192. 
Becker, J.-M., Ringle, C. M., \& Sarstedt, M. (2018). Estimating moderating effects in PLS-SEM and PLSc-SEM: Interaction term generation*data treatment. Journal of Applied Structural Equation Modeling, 2(2), 1-21.

Bellone, C. J., \& Goerl, G. F. (1992). Reconciling public entrepreneurship and democracy. Public Administration Review, 52(2), 130-134.

Bernier, L. (2014). Public enterprises as policy instruments: The importance of public entrepreneurship. Journal of Economic Policy Reform, 17(3), 253-266.

Bernier, L., \& Reeves, E. (2018). The continuing importance of state-owned enterprise in the twentyfirst century: Challenges for public policy. Annals of Public and Cooperative Economics, 89(3), $453-458$.

Blankart, C. B. (1983). The contribution of public choice to public utility economics - a survey. In J. Finsinger (Ed.), Public sector economics (pp. 151-170). Macmillan.

Boivie, S., Bednar, M. K., Aguilera, R. V., \& Andrus, J. L. (2016). Are boards designed to fail? The implausibility of effective board monitoring. Academy of Management Annals, 10(1), 319-407.

Bozec, R., \& Dia, M. (2007). Board structure and firm technical efficiency: Evidence from Canadian state-owned enterprises. European Journal of Operational Research, 177(3), 1734-1750.

Bradshaw, P., Murray, V., \& Wolpin, J. (1992). Do nonprofit boards make a difference? An exploration of the relationships among board structure, process, and effectiveness. Nonprofit and Voluntary Sector Quarterly, 21(3), 227-249.

Brändle, L., Golla, S., \& Kuckertz, A. (2019). How entrepreneurial orientation translates social identities into performance. International Journal of Entrepreneurial Behavior \& Research, 25(7), 1433-1451.

Brislin, R. W. (1970). Back-translation for cross-cultural research. Journal of Cross-Cultural Psychology, 1(3), 185-216.

Bruton, G. D., Peng, M. W., Ahlstrom, D., Stan, C., \& Xu, K. (2015). State-owned enterprises around the world as hybrid organizations. Academy of Management Perspectives, 29(1), 92-114.

Bysted, R., \& Hansen, J. R. (2015). Comparing public and private sector employees' innovative behaviour: Understanding the role of job and organizational characteristics, job types, and subsectors. Public Management Review, 17(5), 698-717.

Bysted, R., \& Jespersen, K. R. (2014). Exploring managerial mechanisms that influence innovative work behaviour: Comparing private and public employees. Public Management Review, 16(2), 217-241.

Cahan, S. F., Chua, F., \& Nyamori, R. O. (2005). Board structure and executive compensation in the public sector: New Zealand evidence. Financial Accountability and Management, 21(4), 437-465.

Calabrò, A., Torchia, M., \& Ranalli, F. (2013). Ownership and control in local public utilities: The Italian case. Journal of Management and Governance, 17(4), 835-862.

Carpenter, M. A., \& Westphal, J. D. (2001). The strategic context of external network ties: Examining the impact of director appointments on board involvement in strategic decision making. Academy of Management Journal, 44(4), 639-660.

Caruana, A., Ewing, M. T., \& Ramaseshan, B. (2002). Effects of some environmental challenges and centralization on the entrepreneurial orientation and performance of public sector entities. The Service Industries Journal, 22(2), 43-58.

Casciaro, T., \& Piskorski, M. J. (2005). Power imbalance, mutual dependence, and constraint absorption: A closer look at resource dependence theory. Administrative Science Quarterly, 50(2), 167-199.

Chambers, N., \& Cornforth, C. (2010). The role of corporate governance and boards in organisational performance. In K. Walshe, G. Harvey, \& P. Jas (Eds.), Connecting knowledge and performance in public services: From knowing to doing (pp. 99-127). Cambridge University Press.

Chin, W. W. (1998). The partial least squares approach to structural equation modeling. In G. A. Marcoulides (Ed.), Modern methods for business research (pp. 295-358). Lawrence Erlbaum Associates Publishers.

Cinar, E., Trott, P., \& Simms, C. (2019). A systematic review of barriers to public sector innovation process. Public Management Review, 21(2), 264-290.

Clark, L. A., \& Watson, D. (1995). Constructing validity: Basic issues in objective scale development. Psychological Assessment, 7(3), 309-319.

Coombes, S. M. T., Morris, M. H., Allen, J. A., \& Webb, J. W. (2011). Behavioural orientations of nonprofit boards as a factor in entrepreneurial performance: Does governance matter? Journal of Management Studies, 48(4), 829-856. 
Covin, J. G., \& Miller, D. (2014). International entrepreneurial orientation: Conceptual considerations, research themes, measurement issues, and future research directions. Entrepreneurship Theory and Practice, 38(1), 11-44.

Covin, J. G., \& Slevin, D. P. (1989). Strategic management of small firms in hostile and benign environments. Strategic Management Journal, 10(1), 75-87.

Covin, J. G., \& Wales, W. J. (2012). The measurement of entrepreneurial orientation. Entrepreneurship Theory and Practice, 36(4), 677-702.

Covin, J. G., \& Wales, W. J. (2019). Crafting high-impact entrepreneurial orientation research: Some suggested guidelines. Entrepreneurship Theory and Practice, 43(1), 3-18.

Cuervo, A., \& Villalonga, B. (2000). Explaining the variance in the performance effects of privatization. Academy of Management Review, 25(3), 581-590.

Daiser, P., Ysa, T., \& Schmitt, D. (2017). Corporate governance of state-owned enterprises: A systematic analysis of empirical literature. International Journal of Public Sector Management, 30(5), 447-466.

Dalton, D. R., Daily, C. M., Ellstrand, A. E., \& Johnson, J. L. (1998). Meta-analytic reviews of board composition, leadership structure, and financial performance. Strategic Management Journal, 19(3), 269-290.

Davies, D. G. (1971). The efficiency of public versus private firms, the case of Australia's two airlines. Journal of Law and Economics, 14(1), 149-165.

Dawes, J. (2008). Do data characteristics change according to the number of scale points used? An experiment using 5-point, 7-point and 10-point scales. International Journal of Market Research, 50(1), 61-77.

de Villiers, C., \& Dimes, R. (2021). Determinants, mechanisms and consequences of corporate governance reporting: A research framework. Journal of Management and Governance, 25, 7-26.

Deman, R., Jorissen, A., \& Laveren, E. (2018). Family control and innovativeness in private firms: The mediating role of board task performance. Management Decision, 56(2), 295-310.

Desender, K. A., Aguilera, R. V., Crespi, R., \& García-Cestona, M. (2013). When does ownership matter? Board characteristics and behavior. Strategic Management Journal, 34(7), 823-842.

Dess, G. G., \& Lumpkin, G. T. (2005). The role of entrepreneurial orientation in stimulating effective corporate entrepreneurship. Academy of Management Executive, 19(1), 147-156.

Dhanaraj, C., \& Parkhe, A. (2006). Orchestrating innovation networks. Academy of Management Review, 31(3), 659-669.

Dicko, S., Khemakhem, H., \& Zogning, F. (2020). Political connections and voluntary disclosure: The case of Canadian listed companies. Journal of Management and Governance, 24(2), 481-506.

Drees, J. M., \& Heugens, P. P. M. A. R. (2013). Synthesizing and extending resource dependence theory: A meta-analysis. Journal of Management, 39(6), 1666-1698.

Eddleston, K. A., Kellermanns, F. W., \& Zellweger, T. M. (2012). Exploring the entrepreneurial behavior of family firms: Does the stewardship perspective explain differences? Entrepreneurship Theory and Practice, 36(2), 347-367.

Fama, E. F., \& Jensen, M. C. (1983). Separation of ownership and control. Journal of Law and Economics, 26(2), 301-325.

Finkelstein, S., \& Mooney, A. C. (2003). Not the usual suspects: How to use board process to make boards better. Academy of Management Executive, 17(2), 101-113.

Florio, M. (2013). Rethinking on public enterprise: Editorial introduction and some personal remarks on the research agenda. International Review of Applied Economics, 27(2), 135-149.

Fornell, C., \& Larcker, D. F. (1981). Evaluating structural equation models with unobservable variables and measurement error. Journal of Marketing Research, 18(1), 39-50.

Gabrielsson, J. (2007). Boards of directors and entrepreneurial posture in medium-size companies: Putting the board demography approach to a test. International Small Business Journal, 25(5), 511-537.

Gabrielsson, J., \& Huse, M. (2017). Governance theory: Origins and implications for researching boards and governance in entrepreneurial firms. In J. Gabrielsson (Ed.), Handbook of research on corporate governance and entrepreneurship (pp. 27-60). Edward Elgar Publishing.

Gabrielsson, J., \& Politis, D. (2009). Board control and innovation: An empirical study of small technologybased firms. In M. Huse (Ed.), The value creating board: Corporate governance and organizational behaviour (pp. 505-519). Routledge.

Gabrielsson, J., \& Winlund, H. (2000). Boards of directors in small and medium-sized industrial firms: Examining the effects of the board's working style on board task performance. Entrepreneurship \& Regional Development, 12(4), 311-330. 
Garrone, P., Grilli, L., \& Rousseau, X. (2013). Management discretion and political interference in municipal enterprises. Evidence from Italian utilities. Local Government Studies, 39(4), 514-540.

Green, K. M., Covin, J. G., \& Slevin, D. P. (2008). Exploring the relationship between strategic reactiveness and entrepreneurial orientation: The role of structure-style fit. Journal of Business Venturing, 23(3), 356-383.

Greer, A., Hoggett, P., \& Maile, S. (2003). Are quasi-governmental organisations effective and accountable? In C. Cornforth (Ed.), The governance of public and non-profit organisations: What do boards do? (pp. 40-56). Routledge.

Grossi, G., \& Reichard, C. (2008). Municipal corporatization in Germany and Italy. Public Management Review, 10(5), 597-617.

Hair, J. F., Ringle, C. M., \& Sarstedt, M. (2011). PLS-SEM: Indeed a silver bullet. Journal of Marketing Theory and Practice, 19(2), 139-152.

Hair, J. F., Risher, J. J., Sarstedt, M., \& Ringle, C. M. (2019). When to use and how to report the results of PLS-SEM. European Business Review, 31(1), 2-24.

Hair, J. F., Sarstedt, M., Ringle, C. M., \& Gudergan, S. P. (2018). Advanced issues in partial least squares structural equation modeling. Sage Publications.

Helmers, C., Patnam, M., \& Rau, P. R. (2017). Do board interlocks increase innovation? Evidence from a corporate governance reform in India. Journal of Banking \& Finance, 80, 51-70.

Henseler, J., Ringle, C. M., \& Sarstedt, M. (2015). A new criterion for assessing discriminant validity in variance-based structural equation modeling. Journal of the Academy of Marketing Science, 43(1), 115-135.

Hideto Dato, M., Hudon, M., \& Mersland, R. (2020). Board governance: Does ownership matter? Annals of Public and Cooperative Economics, 91(1), 5-28.

Hill, C. W. L., \& Jones, T. M. (1992). Stakeholder-agency theory. Journal of Management Studies, 29(2), $131-154$.

Hillman, A. J., \& Dalziel, T. (2003). Boards of directors and firm performance: Integrating agency and resource dependence perspectives. Academy of Management Review, 28(3), 383-396.

Hinna, A., De Nito, E., \& Mangia, G. (2010). Board of directors within public organisations: A literature review. International Journal of Business Governance and Ethics, 5(3), 131-156.

Hinna, A., \& Scarozza, D. (2015). A behavioral perspective for governing bodies. International Studies of Management \& Organization, 45(1), 43-59.

Hinz, V., \& Ingerfurth, S. (2013). Does ownership matter under challenging conditions? On the relationship between organizational entrepreneurship and performance in the healthcare sector. Public Management Review, 15(7), 969-991.

Höglund, L., Mårtensson, M., \& Safari, A. (2018). Expectations and the performance of governance functions between a board, management and other stakeholders: The case of Robotdalen. Journal of Management and Governance, 22(4), 805-827.

Hoppmann, J., Naegele, F., \& Girod, B. (2019). Boards as a source of inertia: Examining the internal challenges and dynamics of boards of directors in times of environmental discontinuities. Academy of Management Journal, 62(2), 437-468.

Huse, M. (2005a). Accountability and creating accountability: A framework for exploring behavioural perspectives of corporate governance. British Journal of Management, 16(S1), 65-79.

Huse, M. (2005b). Corporate governance: Understanding important contingencies. Corporate Ownership and Control, 2(4), 41-50.

Huse, M. (2007). Boards, governance, and value creation: The human side of corporate governance. Cambridge University Press.

Huse, M., Hoskisson, R., Zattoni, A., \& Viganò, R. (2011). New perspectives on board research: Changing the research agenda. Journal of Management and Governance, 15(1), 5-28.

Huse, M., \& Rindova, V. P. (2001). Stakeholders' expectations of board roles: The case of subsidiary boards. Journal of Management and Governance, 5(2), 153-178.

Inoue, C. F. K. V., Lazzarini, S. G., \& Musacchio, A. (2013). Leviathan as a minority shareholder: Firmlevel implications of state equity purchases. Academy of Management Journal, 56(6), 1775-1801.

Jarillo, J. C. (1988). On strategic networks. Strategic Management Journal, 9(1), 31-41.

Jensen, M. C., \& Meckling, W. H. (1976). Theory of the firm: Managerial behavior, agency costs and ownership structure. Journal of Financial Economics, 3(4), 305-360.

Kaczmarek, S., Kimino, S., \& Pye, A. (2014). Interlocking directorships and firm performance in highly regulated sectors: The moderating impact of board diversity. Journal of Management and Governance, $18(2), 347-372$. 
Kearney, C., Hisrich, R. D., \& Roche, F. (2008). A conceptual model of public sector corporate entrepreneurship. International Entrepreneurship and Management Journal, 4(3), 295-313.

Kearney, C., Hisrich, R. D., \& Roche, F. (2010). Change management through entrepreneurship in public sector enterprises. Journal of Developmental Entrepreneurship, 15(4), 415-437.

Kellermanns, F. W., \& Eddleston, K. A. (2006). Corporate entrepreneurship in family firms: A family perspective. Entrepreneurship Theory and Practice, 30(6), 809-830.

Kirchhoff, B. A. (1977). Organization effectiveness measurement and policy research. Academy of Management Review, 2(3), 347-355.

Klausen, J. E., \& Winsvold, M. (2021). Corporate governance and democratic accountability: Local stateowned enterprises in Norway. Journal of Public Policy, 41(1), 161-184.

Kock, N. (2015). Common method bias in PLS-SEM. International Journal of e-Collaboration, 11(4), $1-10$.

Kock, N., \& Lynn, G. S. (2012). Lateral collinearity and misleading results in variance-based SEM: An illustration and recommendations. Journal of the Association for Information Systems, 13(7), $546-580$.

Kollmann, T., \& Stöckmann, C. (2014). Filling the entrepreneurial orientation-performance gap: The mediating effects of exploratory and exploitative innovations. Entrepreneurship Theory and Practice, 38(5), 1001-1026.

Kolloch, M., \& Reck, F. (2017). Innovation networks in the German energy industry: An empirical analysis of inter-organizational knowledge transfer. International Journal of Energy Sector Management, 11(2), 268-294.

Kraus, S., Breier, M., Jones, P., \& Hughes, M. (2019). Individual entrepreneurial orientation and intrapreneurship in the public sector. International Entrepreneurship and Management Journal, 15(4), 1247-1268.

Lee, K., \& Duffy, M. K. (2019). A functional model of workplace envy and job performance: When do employees capitalize on envy by learning from envied targets? Academy of Management Journal, 62(4), 1085-1110.

Li, J. (1994). Ownership structure and board composition: A multi-country test of agency theory predictions. Managerial and Decision Economics, 15(4), 359-368.

Liddle, J., \& McElwee, G. (2019). Theoretical perspectives on public entrepreneurship. International Journal of Entrepreneurial Behavior \& Research, 25(6), 1308-1320.

Lioukas, S., Bourantas, D., \& Papadakis, V. (1993). Managerial autonomy of state-owned enterprises: Determining factors. Organization Science, 4(4), 645-666.

Lomberg, C., Urbig, D., Stöckmann, C., Marino, L. D., \& Dickson, P. H. (2017). Entrepreneurial orientation: The dimensions' shared effects in explaining firm performance. Entrepreneurship Theory and Practice, 41(6), 973-998.

Lumpkin, G. T., \& Dess, G. G. (1996). Clarifying the entrepreneurial orientation construct and linking it to performance. Academy of Management Review, 21(1), 135-172.

Lumpkin, G. T., \& Dess, G. G. (2001). Linking two dimensions of entrepreneurial orientation to firm performance: The moderating role of environment and industry life cycle. Journal of Business Venturing, 16(5), 429-451.

Machold, S., Huse, M., Minichilli, A., \& Nordqvist, M. (2011). Board leadership and strategy involvement in small firms: A team production approach. Corporate Governance: An International Review, 19(4), 368-383.

Mack, W. R., Green, D., \& Vedlitz, A. (2008). Innovation and implementation in the public sector: An examination of public entrepreneurship. Review of Policy Research, 25(3), 233-252.

Mazzucato, M. (2018). The entrepreneurial state: Debunking public vs. private sector myths. Penguin Books.

Meynhardt, T., \& Diefenbach, F. E. (2012). What drives entrepreneurial orientation in the public sector? Evidence from Germany's Federal Labor Agency. Journal of Public Administration Research and Theory, 22(4), 761-792.

Miller, D. (1983). The correlates of entrepreneurship in three types of firms. Management Science, 29(7), $770-791$.

Miller, D. (2011). Miller (1983) revisited: A reflection on EO research and some suggestions for the future. Entrepreneurship Theory and Practice, 35(5), 873-894.

Minichilli, A., \& Hansen, C. (2007). The board advisory tasks in small firms and the event of crises. Journal of Management and Governance, 11(1), 5-22. 
Minichilli, A., Zattoni, A., \& Zona, F. (2009). Making boards effective: An empirical examination of board task performance. British Journal of Management, 20(1), 55-74.

Mitchell, R. K., Mitchell, J. R., \& Smith, J. B. (2008). Inside opportunity formation: Enterprise failure, cognition, and the creation of opportunities. Strategic Entrepreneurship Journal, 2(3), 225-242.

Mizrahi, S., \& Minchuk, Y. (2019). Accountability and performance management: Citizens' willingness to monitor public officials. Public Management Review, 21(3), 334-353.

Mizruchi, M. S. (1996). What do interlocks do? An analysis, critique, and assessment of research on interlocking directorates. Annual Review of Sociology, 22, 271-298.

Monteduro, F. (2014). Public-private versus public ownership and economic performance: Evidence from Italian local utilities. Journal of Management and Governance, 18(1), 29-49.

Moore, M. H. (1995). Creating public value: Strategic management in government. Harvard University Press.

Moreno, A. M., \& Casillas, J. C. (2008). Entrepreneurial orientation and growth of SMEs: A causal model. Entrepreneurship Theory and Practice, 32(3), 507-528.

Morris, M. H., \& Jones, F. F. (1999). Entrepreneurship in established organizations: The case of the public sector. Entrepreneurship Theory and Practice, 24(1), 71-91.

Mühlemeier, S. (2019). Dinosaurs in transition? A conceptual exploration of local incumbents in the Swiss and German energy transition. Environmental Innovation and Societal Transitions, 31, 126-143.

Niskanen, W. A. (1971). Bureaucracy and representative government. Aldine Atherton.

OECD. (2015). OECD guidelines on corporate governance of state-owned enterprises. Retrieved June 22, 2020, from https://www.oecd-ilibrary.org/docserver/9789264244160-en.pdf.

Olsen, T. H., Solstad, E., \& Torsteinsen, H. (2017). The meaning of institutional logics for performance assessment in boards of municipal companies. Public Money \& Management, 37(6), 393-400.

Padilla-Angulo, L. (2020). The impact of board diversity on strategic change: A stakeholder perspective. Journal of Management and Governance, 24(4), 927-952.

Papenfuß, U., \& Keppeler, F. (2020). Does performance-related pay and public service motivation research treat state-owned enterprises like a neglected Cinderella? A systematic literature review and agenda for future research on performance effects. Public Management Review, 22(7), 1119-1145.

Perry, J. L., Hondeghem, A., \& Wise, L. R. (2010). Revisiting the motivational bases of public service: Twenty years of research and an agenda for the future. Public Administration Review, 70(5), 681-690.

Pfeffer, J., \& Salancik, G. R. (1978). The external control of organizations: A resource dependence perspective. Harper \& Row Publishers.

Podsakoff, P. M., MacKenzie, S. B., Lee, J.-Y., \& Podsakoff, N. P. (2003). Common method biases in behavioral research: A critical review of the literature and recommended remedies. Journal of Applied Psychology, 88(5), 879-903.

Podsakoff, P. M., MacKenzie, S. B., \& Podsakoff, N. P. (2012). Sources of method bias in social science research and recommendations on how to control it. Annual Review of Psychology, 63, 539-569.

Podsakoff, P. M., \& Organ, D. W. (1986). Self-reports in organizational research: Problems and prospects. Journal of Management, 12(4), 531-544.

Provan, K. G., Fish, A., \& Sydow, J. (2007). Interorganizational networks at the network level: A review of the empirical literature on whole networks. Journal of Management, 33(3), 479-516.

Ramamurti, R. (1986). Public entrepreneurs: Who they are and how they operate. California Management Review, 28(3), 142-158.

Rauch, A., Wiklund, J., Lumpkin, G. T., \& Frese, M. (2009). Entrepreneurial orientation and business performance: An assessment of past research and suggestions for the future. Entrepreneurship Theory and Practice, 33(3), 761-787.

Ringle, C. M., Wende, S., \& Becker, J.-M. (2015). SmartPLS 3. SmartPLS GmbH.

Roberts, N. C., \& King, P. J. (1991). Policy entrepreneurs: Their activity structure and function in the policy process. Journal of Public Administration Research and Theory, 1(2), 147-175.

Rosenbusch, N., Rauch, A., \& Bausch, A. (2013). The mediating role of entrepreneurial orientation in the task environment-performance relationship: A meta-analysis. Journal of Management, 39(3), 633-659.

Sackett, P. R., \& Larson, J. R. (1990). Research strategies and tactics in industrial and organizational psychology. In M. D. Dunnette \& L. M. Hough (Eds.), Handbook of industrial and organizational psychology (pp. 419-489). Consulting Psychologists Press. 
Sadler, R. J. (2000). Corporate entrepreneurship in the public sector: The dance of the chameleon. Australian Journal of Public Administration, 59(2), 25-43.

Salancik, G. R. (1979). Interorganizational dependence and responsiveness to affirmative action: The case of women and defense contractors. Academy of Management Journal, 22(2), 375-394.

Sarstedt, M., Hair, J. F., Cheah, J.-H., Becker, J.-M., \& Ringle, C. M. (2019). How to specify, estimate, and validate higher-order constructs in PLS-SEM. Australasian Marketing Journal, 27(3), $197-211$.

Schepers, J., Voordeckers, W., Steijvers, T., \& Laveren, E. (2013). Family firm CEO shaping firm-level entrepreneurial orientation: The board of directors as mediator. Academy of Management Proceedings. https://doi.org/10.5465/AMBPP.2013.76

Shih, H.-A., \& Susanto, E. (2011). Is innovative behavior really good for the firm? Innovative work behavior, conflict with coworkers and turnover intention: Moderating roles of perceived distributive fairness. International Journal of Conflict Management, 22(2), 111-130.

Shleifer, A., \& Vishny, R. W. (1994). Politicians and firms. The Quarterly Journal of Economics, 109(4), 995-1025.

Shleifer, A., \& Vishny, R. W. (1997). A survey of corporate governance. The Journal of Finance, 52(2), 737-783.

Sidki, M., \& Boll, D. (2019). What do citizens think about public enterprises? Subjective survey data on the legitimacy of the economic activities of the German public sector. Annals of Public and Cooperative Economics, 90(4), 615-639.

Siegel, S., \& Castellan, N. J. (1988). Nonparametric statistics for the behavioral sciences. McGraw-Hill.

Sievinen, H. M., Ikäheimonen, T., \& Pihkala, T. (2020). The advisory role of non-family board members: A case-based study of a family firm. Journal of Management and Governance, 24(4), 871-903.

Sirén, C. A., Kohtamäki, M., \& Kuckertz, A. (2012). Exploration and exploitation strategies, profit performance, and the mediating role of strategic learning: Escaping the exploitation trap. Strategic Entrepreneurship Journal, 6(1), 18-41.

Smith, E. (2012). Explaining public entrepreneurship in local government organizations. State and Local Government Review, 44(3), 171-184.

Smith, E. (2014). Entrepreneurship at the local government level: Stimulating and restraining forces in the Swedish waste management industry. Public Management Review, 16(5), 708-732.

Sørensen, R. J. (2007). Does dispersed public ownership impair efficiency? The case of refuse collection in Norway. Public Administration, 85(4), 1045-1058.

Tenenhaus, M., Vinzi, V. E., Chatelin, Y.-M., \& Lauro, C. (2005). PLS path modeling. Computational Statistics \& Data Analysis, 48(1), 159-205.

Thornton, P. H., \& Ocasio, W. (1999). Institutional logics and the historical contingency of power in organizations: Executive succession in the higher education publishing industry, 1958-1990. American Journal of Sociology, 105(3), 801-843.

Tremml, T. (2020). Barriers to entrepreneurship in public enterprises: Boards contributing to inertia. Public Management Review. https://doi.org/10.1080/14719037.2020.1775279

Weber, K. M., Heller-Schuh, B., Godoe, H., \& Roeste, R. (2014). ICT-enabled system innovations in public services: Experiences from intelligent transport systems. Telecommunications Policy, 38(5/6), 539-557.

Weijters, B., Cabooter, E., \& Schillewaert, N. (2010). The effect of rating scale format on response styles: The number of response categories and response category labels. International Journal of Research in Marketing, 27(3), 236-247.

Westphal, J. D. (1999). Collaboration in the boardroom: Behavioral and performance consequences of CEO-board social ties. Academy of Management Journal, 42(1), 7-24.

Zattoni, A., Gnan, L., \& Huse, M. (2015). Does family involvement influence firm performance? Exploring the mediating effects of board processes and tasks. Journal of Management, 41(4), 1214-1243.

Zona, F., Gomez-Mejia, L. R., \& Withers, M. C. (2018). Board interlocks and firm performance: Toward a combined agency-resource dependence perspective. Journal of Management, 44(2), 589-618.

Publisher's Note Springer Nature remains neutral with regard to jurisdictional claims in published maps and institutional affiliations. 